\title{
Effect of Variety and Storage on the Tuber Quality of Potatoes Cultivated in the Eastern Highlands of Ethiopia
}

\author{
Addisu S. Chemeda ${ }^{1}$, Geremew Bultosa ${ }^{1,2^{\star}}$ and Nigussie Dechassa ${ }^{3}$ \\ ${ }^{1}$ Department of Food Science and Postharvest Technology, Haramaya University, Post Box No: 138, \\ Dire Dawa, Ethiopia \\ ${ }^{2}$ Department of Food Science and Technology, Botswana College of Agriculture, Gaborone, Botswana \\ ${ }^{3}$ Department of Plant Sciences, Haramaya University, Post Box No: 138, Dire Dawa, Ethiopia
}

\begin{tabular}{|c|c|}
\hline Abstract & Article Information \\
\hline $\begin{array}{l}\text { Eight potato varieties: five improved and released by Haramaya University and three } \\
\text { from smallholders potato farmers variety (eastern Hararghe, Oromia, Ethiopia) were } \\
\text { planted following cultural practices in RCBD with three replications to assess tuber } \\
\text { quality and storage performance differences. Tubers were harvested in } 2011 \text {. After } \\
\text { curing at } 15-18^{\circ} \mathrm{C} \text { and relative humidity of } 75-82 \% \text { for one week, the tubers were } \\
\text { separately stored at } 8-16^{\circ} \mathrm{C} \text { and relative humidity of } 69-83 \% \text { for } 20,40 \text {, and } 60 \text { days in } \\
\text { a ventilated storehouse in CRD with three replication per treatment. The results } \\
\text { showed significant differences }(P<0.05) \text { due to variety. Storage duration significantly } \\
\text { reduced dry matter, specific gravity and amylose contents with no significant changes } \\
\text { in ash, crude fibre, potassium and phosphorus contents. The highest dry matter, } \\
\text { specific gravity, and amylose contents were obtained for the improved variety Chala } \\
\text { whereas the lowest was for the farmers' variety Jarso. The highest crude protein } \\
\text { content was recorded for the farmers' variety Mashenadima and the lowest was for the } \\
\text { improved variety Zemen. The results revealed that potato tubers with superior } \\
\text { physicochemical qualities, most of which are released varieties retained their qualities } \\
\text { after storage for longer durations, whereas those with lower qualities could be stored } \\
\text { only for shorter durations. } \\
\text { Copyright@2014 STAR Journal. All Rights Reserved. }\end{array}$ & $\begin{array}{l}\text { Article History: } \\
\text { Received : 07-01-2014 } \\
\text { Revised : 25-03-2014 } \\
\text { Accepted : 28-03-2014 } \\
\text { Keywords: } \\
\text { Amylose } \\
\text { Potato } \\
\text { Storage } \\
\text { Tuber Quality } \\
\text { Variety } \\
\text { *Corresponding Author: } \\
\text { Geremew Bultosa } \\
\text { E-mail: } \\
\text { bultosageremew@yahoo.com }\end{array}$ \\
\hline
\end{tabular}

\section{INTRODUCTION}

Next to wheat, rice and maize, potato (Solanum tuberosum L.) is one of the most important food crops of the world. In Ethiopia, its production in 2012/2013 was estimated to be 0.86 million tonnes (CSA, 2012/13) from an area of 0.7 million hectares by 1.6 million smallholder farmers. Potato is regarded as a high-potential food security crop because of its ability to provide a high yield of high-quality product per unit input with a shorter crop cycle (mostly <120 days) than the major cereal crops (Adane et al., 2010).

The quality of potato tubers, as in all horticultural produce, is closely linked to the chemical characteristics of the tubers (specific gravity, dry matter, starch to reducing sugar ratio, amylose $\%$, minerals and vitamin C) and varies widely in relation to different factors such as climate, growing conditions, variety, maturity at harvest and harvesting methods (Bentini et al., 2006). Storage conditions can also influence these characteristics (Burton, 1989). The most important features of potato production are its tuber quality. Each potato variety has unique tuber chemical composition. Freshly harvested potatoes contain about $75 \%$ water and $25 \%$ dry matter.
Some $65-75 \%$ of the dry matter of the potato tuber is starch (Burton 1989). The dry matter content of most varieties selected for commercial use is in the range of 18 to $26 \%$ (Burton, 1989). Dry matter is an important aspect of tuber quality and is affected by a wide range of factors, including most importantly, environmental factors during growth of the crop and development of the tuber, variety and storage conditions. Potato tuber is low in fat and rich in several micronutrient minerals $(\mathrm{K}, \mathrm{Mg}, \mathrm{Ca}, \mathrm{Na}, \mathrm{Fe}$ and Zn) (Luis et al., 2011) and vitamin C (Hrabovská et al., 2013). Since potato varieties vary widely in tuber chemical qualities, the choice of variety is probably the most critical decision with respect to matching tuber quality with the intended market. Quality of the potato tuber has been found to vary between and within varieties when grown under different cultural and environmental conditions. Preharvest (fertilizer applied, growing environment, tuber maturity at harvest and harvesting methods), postharvest operation (curing, storage conditions like temperature, relative humidity, light and processing methods) factors and variety are the main factors that will influence potato tuber quality (Karenlampi and White, 2009). Potato tubers are either stored under controlled conditions or processed 
Addisu S. Chemeda et al.,

for consumption after harvest. Storage conditions can promote extensive changes in the chemical composition of potato tubers influencing quality characteristics of the final products (Spychalla and Desborough, 1990). If the storage area is dark and well ventilated, the quality of potato tubers can be preserved. If potato tubers are stored at less than $8^{\circ} \mathrm{C}$, its starch contents will be decreased because of conversion to reducing sugars whereas prolonged storage between 10 to $20^{\circ} \mathrm{C}$ is known to increase starch contents, because of starch biosynthesis from the reducing sugars (Lefort et al., 2003).

About seven improved potato varieties have been released by Haramaya University, Ethiopia. In developing the varieties, much emphasis was given to tuber productivity per unit area and disease resistance without due consideration for the physicochemical quality of the tubers. Particularly, information on variations of the potato tuber varieties and the influence of storage period with the use of locally constructed storage facilities on postharvest quality of potato tubers for varieties developed in the country is limited. In addition, information on tuber quality attributes of both local and improved potato varieties is limited. Thus, it is difficult to identify varieties for particular end use such as for processing into chips and French fries. Hence, this study was initiated to investigate the effect of varieties and storage durations on physicochemical qualities of tubers from different potato varieties.

\section{MATERIALS AND METHODS}

\section{Experimental Site}

The storage study was conducted in Baatee town, which is located in the vicinity (about $1.5 \mathrm{~km}$ to the east) of Haramaya University $\left(09^{\circ} 25^{\prime} 03^{\prime \prime} \mathrm{N}\right.$ latitude and $42^{\circ}$ 02'58" E longitude and at an altitude of 2051 meters above sea level). The laboratory analysis was conducted at the Department of Food Science and Postharvest Technology, Haramaya University, Ethiopia.

\section{Experimental Materials}

The experimental materials consisted of five improved potato varieties released by Haramaya University over the past 15 years (Gabbisa, Zemen, Badhasa, Chiro and Chala) and three local/farmers' varieties (Batte, Jarso and Mashenadima) that were selected and developed by smallholder potato farmers in the eastern Hararghe highlands, Oromiya, Ethiopia. The potato varieties were planted in a randomized complete block design (RCBD) with three replications in July 2011 in plots at the spacing of $75 \mathrm{~cm}$ between ridges and $30 \mathrm{~cm}$ between tubers. Uniform cultural practices were adopted for all other cultivation and crop managements. At crop maturity, dehaulming was done 15 days before harvesting to toughen the tuber periderm, so as to pre-empt the likelihood of bruising and skinning. The tubers were then harvested in December 2011.

\section{Treatments and Experimental Design}

The treatments consisted of eight potato varieties and four storage durations (initial storage day = control, 20 days, 40 days, and 60 days) in a CRD with a factorial arrangement and the physicochemical qualities of all potato tuber varieties were evaluated at a 20 days interval.
Sci. Technol. Arts Res. J., Jan-March 2014, 3(1): 84-89

\section{Potato Tuber Storage Warehouse}

The inside and outside walls of the storage house were made up of mud with thickness of about $10 \mathrm{~cm}$ (Figure 1). The roof was constructed from corrugated iron sheet metals in the outer part with chip wood as ceiling on the inside part. The storehouse had four windows used for air circulation, which were internally covered by a wire mesh and had one door which was used for loading and unloading. The windows were kept closed and opened during days and nights, respectively to prevent entrance of light and to create darkness and to allow dissipation of heat and carbon dioxide produced by the tubers due to respiration. The internal part was installed with wooden shelves of different bed structures to hold tubers of the different potato varieties separately. The temperature and relative humidity of the surrounding environment and inside the warehouse was between $12-20^{\circ} \mathrm{C}, 35-52 \%$ and $8-16^{\circ} \mathrm{C}, 72-83 \%$, respectively, throughout the storage period.

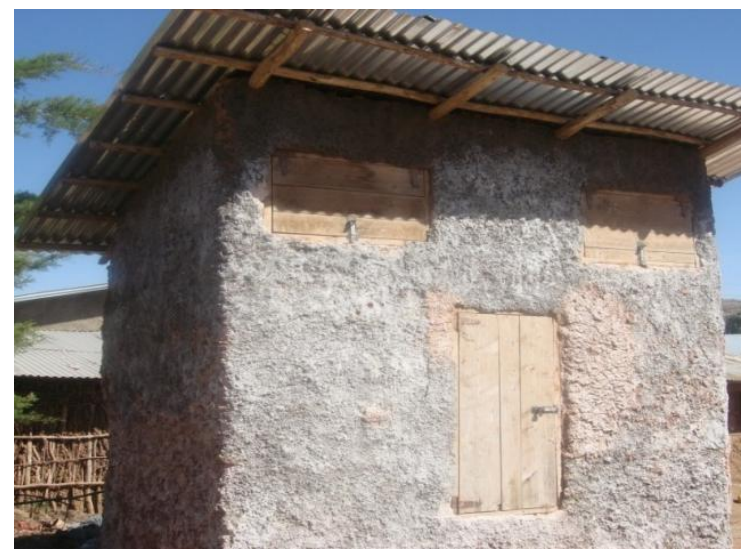

Figure 1: Potato tuber storage warehouse.

Before storage trial, the potato tubers were cured under a shade by spreading on the floor and covering thinly with a layer of grass straw for one week at the temperature of $15-18^{\circ} \mathrm{C}$ and relative humidity of $75-82 \%$. After curing, potato tubers showing greening, symptoms of diseases any decay or damage were discarded and the remaining sound potato tubers were stored in the warehouse on the partitioned beds.

\section{Data Collection and Measurement}

Specific Gravity: The specific gravity was determined by taking $3 \mathrm{~kg}$ of potato tubers randomly as the ratio of tuber weight in air to the weight of water displaced by the tuber (Gould, 1995).

$$
\text { Specific gravity }=\frac{\text { Weight in air }}{\text { Weight in air }- \text { Weight in water }}
$$

Dry Matter Content: The dry matter content was determined after drying $200 \mathrm{~g}$ sample (sampled from ten randomly taken tubers that were washed, chopped in to small slices of $1.8 \mathrm{~mm}$ and mixed) in a two stage drying $\left(60^{\circ} \mathrm{C}\right.$ for 15 hours and $105^{\circ} \mathrm{C}$ for 3 hours) in forced air draught oven (Model: 101-1A; Tianjin Taisite Instrument Co., Ltd, Tiajin, China) as the ratio between dry and fresh mass and expressed in percentage (Elfinesh et al., 2011).

$$
\operatorname{Drymatter}(\%)=\frac{\text { Dryweight }}{\text { Fresh weight }} x 100
$$


Addisu S. Chemeda et al.,

\section{Chemical Analysis on Potato Tubers}

Sample Preparation: Potato tubers were sorted, washed, peeled, sliced and dried using an oven drying method. Dried samples were finely ground using a mortar and pestle and the flour was sealed in plastic bags and stored in a refrigerator temperature $\left(4^{\circ} \mathrm{C}\right)$ until analysis.

Amylose (\%) was determined by measuring the blue color of iodine binding with amylose by taking $55 \mathrm{mg}$ potato flour using a UV-Vis spectrophotometer (Jenway Ltd, model 6505, SN 2019, Essex, UK) at $620 \mathrm{~nm}$ (Chrastil, 1987). Amylose content was determined from a standard calibration curve constructed by mixing potato amylose $(0-100 \%)$ of $10 \%$ variations with maize amylopectin. Normal maize starch (Merck UniLAB, code 5871400 ) of $28 \%$ amylose was used as a control. Crude protein content was determined by micro-Kjeldahl method (digester F30100184, SN 111051, VELP Scientifica; distiller F30200191, SN 111526, Europe) of nitrogen analysis (\% protein $=\% \mathrm{~N} \times 6.25)$ by taking about $1.0 \mathrm{~g}$ potato flour (AOAC, 1995) using urea as a control in the analysis. Ash content was determined after carbonization of about $2.0 \mathrm{~g}$ potato flour and ashing $\left(525^{\circ} \mathrm{C}\right)$ in a muffle furnace (Model: MF 120, SN: 04- 1524, Ankara-Turkey) until ashing was complete (AOAC, 1995). Crude fiber content was determined by taking potato flour sample (about $3.0 \mathrm{~g}$ ) as a portion of carbohydrate that resisted sulfuric acid (1.25\%) and $\mathrm{NaOH}(1.25 \%)$ digestion followed by sieving $(75 \mu \mathrm{m})$, washing, drying and ignition to subtract ash from fiber (AOAC, 1995). Phosphorus content was determined after digestion of potato flour (about $10 \mathrm{mg}$ ) and measuring the absorbance of phosphomolybdate blue color at $822 \mathrm{~nm}$ with UV-Vis spectrophotometer (Morrison, 1964). Phosphorus content was estimated from a series of standard (0.2-1.2 $\mu \mathrm{g}$ $\mathrm{P} / \mathrm{mL}$ ) calibration curve prepared from $\mathrm{K}_{2} \mathrm{HPO}_{4}$ Potassium content was determined after dry digestion of potato flour sample (about $2.0 \mathrm{~g}$ ) by Atomic Absorption Spectrophotometer (Model 210 VGP spectrophotometer, Buck Scientific, East Norwalk, CT, USA) at $766.5 \mathrm{~nm}$ using air-acetylene as a source of energy for atomization and $0.1 \%$ cesium chloride solution as ionization suppressant (AACC, 2000). Potassium content was then estimated from a standard calibration curve $(0.0-2.5 \mu \mathrm{g}$ $\mathrm{K} / \mathrm{mL}$ ) prepared from $\mathrm{KCl}$.

\section{Statistical Analysis}

Data were subjected to analysis of variance using SAS statistical package (version 9.1, SAS Institute Inc., Cary,
Sci. Technol. Arts Res. J., Jan-March 2014, 3(1): 84-89

NC, USA) to determine differences among the treatments (variety and storage duration) on the physicochemical quality of potato tubers. Mean separation was compared using Fisher's least significant difference (LSD) test at 5\% level of significance.

\section{RESULTS AND DISCUSSION}

\section{Tuber Dry Matter Content and Specific Gravity}

The main effects of variety and storage duration significantly $(P \leq 0.05)$ influenced the tuber dry matter and specific gravity of the potato tubers (Table 1). The highest dry matter was obtained for Chala $(25.92 \%)$, closely followed by Gabbisa (25.17\%) and the lowest was for Jarso (18.27\%). The highest specific gravity was obtained for Chala (1.103), followed by Gabbisa (1.098), Batte (1.096) and Badhasa (1.096) and the lowest was for Jarso (1.068). The dry matter and specific gravity of tubers decreased significantly with increase in the storage duration. Potato tubers dry matter and specific gravity were highest at initial storage day which was statistical parity with potato tubers stored for 20 days. This shows tubers could be stored without losing dry matter yield and specific gravity under the storage method used for about 20 days. But as the storage time progressed to 40 and 60 days, there were significant decreases in the dry matter yield and specific gravity. Corroborating this result, Freitas et al., (2012) reported a significant decreasing trend in the specific gravity and dry matter contents of the potato tubers stored for 180 days at $12^{\circ} \mathrm{C}$. The decrease in the potato tuber dry matter and specific gravity in response to the prolonged duration of storage can be attributed to the gradual respiratory biochemical starch breakdown to sugars that is used up to maintain life of the tuber with concurrent production of carbon dioxide and water vapour (Bisognin et al., 2008). Potato tuber dry matter contents and specific gravity are predictors of the potato tubers end use quality. Tubers with high dry matter and specific gravity generally give higher yields of French fries or chips of low oil absorption (less calorie impact benefit to health) and better texture and are more economical to process (Rommens et al., 2010). Potato tuber with dry matter contents greater than $20 \%$ and specific gravity of greater than 1.08 are the most preferred for processing of tuber into different potato products (Lefort et al., 2003; Abebe et al., 2013). Except the farmers' Jarso variety, all the potato tuber varieties meet these requirements even though there was a reduction in the tuber quality as the storage progressed to 60 days.

Table 1: Main effects of variety and storage durations on dry matter, specific gravity, amylose $\%$ and crude protein content of 8 potato tuber varieties stored for 60 days.

\begin{tabular}{|c|c|c|c|c|}
\hline Varieties & Dry Matter (\%) & Specific gravity & Amylose \% & Crude protein\%\# \\
\hline Badhasa & $24.86 \pm 0.18^{\mathrm{C}}$ & $1.096 \pm 0.003^{b}$ & $16.29 \pm 0.80^{b}$ & $7.45 \pm 0.27^{b}$ \\
\hline Batte & $24.61 \pm 0.39^{d}$ & $1.096 \pm 0.003^{b}$ & $16.30 \pm 1.06^{\mathrm{b}}$ & $6.57 \pm 0.27^{\mathrm{cd}}$ \\
\hline Chala & $25.92 \pm 0.14^{\mathrm{a}}$ & $1.103 \pm 0.004^{a}$ & $16.85 \pm 0.59^{a}$ & $7.35 \pm 0.10^{\mathrm{b}}$ \\
\hline Chiro & $21.66 \pm 0.34^{e}$ & $1.087 \pm 0.002^{\mathrm{C}}$ & $16.06 \pm 0.65^{c}$ & $6.52 \pm 0.29^{d}$ \\
\hline Gabbisa & $25.17 \pm 0.28^{b}$ & $1.098 \pm 0.002^{\mathrm{b}}$ & $15.97 \pm 0.12^{c}$ & $6.68 \pm 0.15^{\mathrm{c}}$ \\
\hline Jarso & $18.27 \pm 0.45^{g}$ & $1.068 \pm 0.008^{\mathrm{e}}$ & $13.82 \pm 1.60^{\dagger}$ & $6.53 \pm 0.15^{\mathrm{d}}$ \\
\hline Mashena Dima & $21.73 \pm 0.24^{\mathrm{e}}$ & $1.088 \pm 0.004^{\mathrm{C}}$ & $14.94 \pm 1.33^{\mathrm{e}}$ & $7.66 \pm 0.07^{\mathrm{a}}$ \\
\hline Zemen & $20.69 \pm 0.40^{\dagger}$ & $1.080 \pm 0.003^{\mathrm{d}}$ & $15.43 \pm 1.04^{\mathrm{d}}$ & $5.87 \pm 0.08^{\mathrm{e}}$ \\
\hline \multicolumn{5}{|c|}{ Storage durations (day of storage) } \\
\hline $1^{\text {st }}$ & $23.06 \pm 2.48^{\mathrm{a}}$ & $1.092 \pm 0.010 a$ & $16.69 \pm 0.72^{\mathrm{a}}$ & $6.76 \pm 0.61^{\mathrm{c}}$ \\
\hline $20^{\text {th }}$ & $23.05 \pm 2.49^{\mathrm{a}}$ & $1.092 \pm 0.010 \mathrm{a}$ & $16.25 \pm 0.69^{b}$ & $6.90 \pm 0.59^{\mathrm{a}}$ \\
\hline $40^{\text {th }}$ & $22.85 \pm 2.59^{b}$ & $1.089 \pm 0.011 b$ & $15.36 \pm 1.10^{c}$ & $6.85 \pm 0.60^{\mathrm{ab}}$ \\
\hline $60^{\text {th }}$ & $22.50 \pm 2.70^{c}$ & $1.085 \pm 0.013 c$ & $14.52 \pm 1.42^{\mathrm{d}}$ & $6.80 \pm 0.61^{\mathrm{bc}}$ \\
\hline CV (\%) & 0.88 & 0.25 & 1.08 & 1.96 \\
\hline
\end{tabular}


Addisu S. Chemeda et al.,

\section{Amylose Content of the Potato Tuber Starch}

The main effect of variety and storage duration, and their interactions significantly $(P<0.05)$ influenced the amylose contents of the potato tubers (Table 2). The highest amylose (17.54\% and $17.42 \%$ ) was recorded for Chala and Batte varieties at the first day of storage. This was closely followed by Chala (17.17\%) and Batte $(17.04 \%)$ on the $20^{\text {th }}$ day of storage duration. However, the lowest amylose content (11.68\%) was recorded for Jarso variety in response to storing for 60 days. In general, amylose contents of all the potato tuber varieties significantly deceased over the storage durations. The
Sci. Technol. Arts Res. J., Jan-March 2014, 3(1): 84-89

highest amylose \% losses during 60 days of storage period were recorded for the varieties Mashenadima (3.05\%) and Zemen (2.75\%) and the lowest loss was for Gabbisa (0.27\%). The decline in the amylose contents in response to prolonging storage durations are most probably attributed to the conditions that favour enzymatic conversion of starch to sugars, thereby resulted into amylose contents reduction (Kaur et al., 2007). The presence or absence of amylose contents in starches has a great influence on the physicochemical properties of the starches and are determinant for the quality of range of products processed from the potato tubers (Kraak, 1993).

Table 2: Interaction effect of variety and storage duration on amylose (\%) of 8 potato tuber varieties stored for 60 days.

\begin{tabular}{|c|c|c|c|c|}
\hline \multirow[t]{2}{*}{ Variety } & \multicolumn{4}{|c|}{ Storage duration (Day of Storage) } \\
\hline & $1^{\text {st }}$ & $20^{\text {th }}$ & $40^{\text {th }}$ & $60^{\text {th }}$ \\
\hline Badhasa & $17.10 \pm 0.34^{\mathrm{cd}}$ & $16.78 \pm 0.19^{\text {ef }}$ & $16.14 \pm 0.05^{\mathrm{hi}}$ & $15.13 \pm 0.09^{\mathrm{mno}}$ \\
\hline Batte & $17.42 \pm 0.26^{\mathrm{ab}}$ & $17.04 \pm 0.03^{\text {cde }}$ & $15.87 \pm 0.11^{\mathrm{jk}}$ & $14.87 \pm 0.11^{\circ}$ \\
\hline Chala & $17.54 \pm 0.29^{a}$ & $17.17 \pm 0.15^{\mathrm{bc}}$ & $16.54 \pm 0.29^{\mathrm{fg}}$ & $16.15 \pm 0.03^{h i}$ \\
\hline Chiro & $16.91 \pm 0.07^{\text {cde }}$ & $16.21 \pm 0.05^{\mathrm{h}}$ & $15.91 \pm 0.07^{\mathrm{jjk}}$ & $15.19 \pm 0.01^{\mathrm{mn}}$ \\
\hline Gabbisa & $16.10 \pm 0.11^{\mathrm{hij}}$ & $16.02 \pm 0.07^{\mathrm{hij}}$ & $15.92 \pm 0.07^{\mathrm{jjk}}$ & $15.83 \pm 0.04^{\mathrm{jk}}$ \\
\hline Jarso & $15.39 \pm 0.13^{\mathrm{Im}}$ & $15.08 \pm 0.09^{\text {no }}$ & $13.12 \pm 0.10^{q}$ & $11.68 \pm 0.53^{r}$ \\
\hline Mashena Dima & $16.27 \pm 0.15^{\mathrm{gh}}$ & $16.04 \pm 0.05^{\text {hij }}$ & $14.22 \pm 0.12^{p}$ & $13.22 \pm 0.12^{q}$ \\
\hline Zemen & $16.83 \pm 0.08^{\mathrm{ed}}$ & $15.65 \pm 0.19^{\mathrm{kl}}$ & $15.18 \pm 0.12^{\mathrm{mn}}$ & $14.08 \pm 0.08^{p}$ \\
\hline $\begin{array}{l}\text { CV (\%) } \\
\text { Where, CV =c }\end{array}$ & $\begin{array}{l}1.08 \\
\text { tion; valu }\end{array}$ & & & \\
\hline
\end{tabular}

\section{Crude Protein (CP) Contents}

The CP contents of all varieties differed significantly over the storage durations. With the increase in the storage duration an increase in the $\mathrm{CP}$ contents were observed for some varieties (e.g. Badhasa) whereas for some other varieties (e.g. Chala) a decrease in CP content was observed. Still in some other varieties (e.g. Mashenadima) the similar CP contents were maintained. The highest tuber CP contents were recorded for the variety Mashenadima $(7.68,7.71,7.64$ and $7.60 \%$, dry matter basis, $\mathrm{db}$ ) on the $1^{\mathrm{st}}, 20^{\text {th }}, 40^{\text {th }}$ and $60^{\text {th }}$ days of storage, respectively on the dry matter basis. The lowest $(5.80,5.92,5.85$ and $5.93 \%$, db) CP contents were observed for the variety Zemen on the $1^{\text {st }}, 20^{\text {th }}, 40^{\text {th }}$ and $60^{\text {th }}$ days of storage, respectively (Table 3). The CP content increased for some varieties up to the $40^{\text {th }}$ days of storage after which it had decreased as the storage period was prolonged. This result is consistent with that of Susana et al. (1985) who reported a similar change in the $\mathrm{CP}$ contents over the storage duration. The result shows that the protein could be degraded or synthesized during storage. This decrease as well as increase in the protein contents of the potato varieties in this study was similar with the changes observed by Nowak (1977). Thus, the increase or decrease in the CP contents of tubers observed in this study may have occurred due to differences in the varieties and their different responses to the storage environments (Josée et al., 1993).

Table 3: Interaction effect of variety and storage duration on crude protein (\%, dry matter basis) of 8 potato tuber varieties stored for 60 days.

\begin{tabular}{|c|c|c|c|c|}
\hline Variety & $\begin{array}{c}\text { Storage durat } \\
1^{\mathrm{st}}\end{array}$ & $20^{\text {th }}$ & $40^{\text {th }}$ & $60^{\text {th }}$ \\
\hline Badhasa & $7.08 \pm 0.03^{\dagger}$ & $7.60 \pm 0.05^{\mathrm{abc}}$ & $7.50 \pm 0.25^{\mathrm{abcd}}$ & $7.62 \pm 0.23^{\mathrm{ab}}$ \\
\hline Batte & $6.73 \pm 0.13^{g h i}$ & $6.72 \pm 0.08^{\mathrm{ghi}}$ & $6.28 \pm 0.26^{\mathrm{mn}}$ & $6.53 \pm 0.34^{\mathrm{ijkl}}$ \\
\hline Chala & $7.45 \pm 0.06^{\mathrm{bcd}}$ & $7.38 \pm 0.06^{\text {cde }}$ & $7.34 \pm 0.05^{\mathrm{de}}$ & $7.22 \pm 0.06^{\mathrm{ef}}$ \\
\hline Chiro & $6.13 \pm 0.13^{\text {no }}$ & $6.70 \pm 0.05^{\text {ghij }}$ & $6.82 \pm 0.03^{9}$ & $6.43 \pm 0.15^{\mathrm{klm}}$ \\
\hline Gabbisa & $6.60 \pm 0.10^{\mathrm{hijkl}}$ & $6.70 \pm 0.10^{\text {ghij }}$ & $6.76 \pm 0.12^{g h}$ & $6.64 \pm 0.25^{\text {ghijk }}$ \\
\hline Jarso & $6.57 \pm 0.08^{\mathrm{hijkl}}$ & $6.50 \pm 0.05^{\mathrm{jklm}}$ & $6.65 \pm 0.15^{\text {ghijk }}$ & $6.41 \pm 0.20^{\mathrm{Im}}$ \\
\hline Mashena Dima & $7.68 \pm 0.06^{a}$ & $7.71 \pm 0.07^{\mathrm{a}}$ & $7.64 \pm 0.09^{\mathrm{ab}}$ & $7.60 \pm 0.04^{\mathrm{ab}}$ \\
\hline Zemen & $5.80 \pm 0.05^{\mathrm{p}}$ & $5.92 \pm 0.05^{\mathrm{op}}$ & $5.85 \pm 0.10^{p}$ & $5.93 \pm 0.07^{\mathrm{op}}$ \\
\hline $\begin{array}{l}\text { CV (\%) } \\
\text { Where, CV = coettic }\end{array}$ & $\begin{array}{l}1.96 \\
\text {; values at }\end{array}$ & 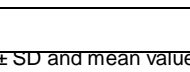 & & \\
\hline
\end{tabular}

\section{Crude Fiber and Total Ash}

The crude fiber and total ash contents were significantly $(P<0.05)$ influenced by variety but not by storage duration and the interaction effects of variety and storage durations. The genetic differences among the potato varieties may have accounted for the differences in the tuber crude fiber and ash contents. Variety Chiro had the highest $(2.51 \%, \mathrm{db})$ crude fiber contents followed by Gabbisa $(2.40 \%, \mathrm{db})$ and Mashenadima $(2.03 \%, \mathrm{db})$, and the lowest was for Zemen $(1.00 \%, \mathrm{db})$. In general, the 
Addisu S. Chemeda et al.,

tuber crude fiber contents had ranged from 1.0-2.5\%, db, which is similar to the previous report $(1.00-2.48 \%, \mathrm{db})$ by Abong et al. (2009).

The highest tuber ash $(4.5 \%, \mathrm{db})$ content was scored for the Jarso variety followed by Batte $(3.98 \%, \mathrm{db})$ and the lowest was recorded for Chiro $(3.02 \%, \mathrm{db})$. The ash contents in the potato tuber of Badhasa, Chala, Gabbisa, and Mashenadima and Zemen were intermediate and in the statistical parity (Table 4). The ash contents for the
Sci. Technol. Arts Res. J., Jan-March 2014, 3(1): 84-89

potato tuber varieties in this work are similar to the values reported (mean 4.68\%, db) by Lewul et al., (2010) for different potato varieties in South Africa. The significant differences in the tuber ash contents among the potato tuber varieties in this study could be attributed to varietal differences as suggested by Woolfe (1987). Total ash contains some important minerals and trace elements essential for various body structures and functions (Burton, 1989).

Table 4: Main effects of varieties and storage duration on total ash, crude fiber, $\mathrm{P}$ and $\mathrm{K}$ contents of 8 potato tuber varieties stored for 60 days.

\begin{tabular}{|c|c|c|c|c|}
\hline Varieties & Total ash (\%)\# & Crude fiber (\%)\# & $P(\mathrm{mg} / 100 \mathrm{~g}) \#$ & $\mathrm{~K}(\mathrm{mg} / 100 \mathrm{~g}) \#$ \\
\hline Badhasa & $3.50 \pm 0.01^{\mathrm{c}}$ & $1.51 \pm 0.01^{\mathrm{e}}$ & $43.57 \pm 0.03^{c}$ & $605.04 \pm 0.34^{b}$ \\
\hline Batte & $3.98 \pm 0.04^{b}$ & $1.50 \pm 0.01^{\mathrm{e}}$ & $35.64 \pm 0.05^{\mathrm{g}}$ & $580.83 \pm 0.44^{f}$ \\
\hline Chala & $3.49 \pm 0.01^{\mathrm{c}}$ & $1.50 \pm 0.01^{\mathrm{e}}$ & $43.44 \pm 0.09^{d}$ & $588.07 \pm 0.11^{\mathrm{e}}$ \\
\hline Chiro & $3.02 \pm 0.05^{d}$ & $2.51 \pm 0.01^{\mathrm{a}}$ & $45.13 \pm 0.02^{b}$ & $518.12 \pm 0.09^{g}$ \\
\hline Gabbisa & $3.50 \pm 0.01^{c}$ & $2.40 \pm 0.01^{\mathrm{b}}$ & $40.18 \pm 0.03^{\mathrm{e}}$ & $601.18 \pm 0.27^{c}$ \\
\hline Jarso & $4.50 \pm 0.01^{\mathrm{a}}$ & $1.71 \pm 0.01^{\mathrm{d}}$ & $45.17 \pm 0.02^{\mathrm{a}}$ & $610.17 \pm 0.12^{a}$ \\
\hline Mashena Dima & $3.50 \pm 0.01^{\mathrm{c}}$ & $2.03 \pm 0.05^{c}$ & $35.17 \pm 0.03^{h}$ & $598.22 \pm 0.14^{d}$ \\
\hline Zemen & $3.50 \pm 0.01^{c}$ & $1.00 \pm 0.01^{\dagger}$ & $38.80 \pm 0.07^{f}$ & $457.11 \pm 0.09^{h}$ \\
\hline CV (\%) & 0.73 & 1.29 & 2.09 & 2.44 \\
\hline
\end{tabular}

not significantly different at $5 \%$ level of significance; \#=dry matter basis

\section{Potassium and Phosphorus Contents}

The potato tuber potassium and phosphorus contents were significantly $(P<0.05)$ influenced by the variety effect but not by the storage duration and the interaction effect of variety and storage durations (Table 4) and similar difference among the varieties were reported for potato (Randhawa et al. 1984). The potassium contents of the potato tuber of the different varieties differed significantly. The highest potassium content $(610.17 \mathrm{mg} / 100 \mathrm{~g} \mathrm{db})$ was observed for Jarso variety, followed by Badhasa $(605.04 \mathrm{mg} / 100 \mathrm{~g}, \mathrm{db})$ and Gabbisa $(601.18 \mathrm{mg} / 100 \mathrm{~g}, \mathrm{db})$. The lowest $(457.11 \mathrm{mg} / 100 \mathrm{~g}, \mathrm{db})$ was recorded for Zemen variety followed by Chiro $(518.12 \mathrm{mg} / 100 \mathrm{~g}$, db) variety. Potato tubers are an important source of different dietary minerals and are best known as an important source of dietary potassium which plays a fundamental role in acidbase regulation and human fluid balances.

The highest phosphorus content $(45.17 \mathrm{mg} / 100 \mathrm{~g}, \mathrm{db})$ was recorded for Jarso followed by Chiro $(45.13 \mathrm{mg} / 100 \mathrm{~g}$, $\mathrm{db})$, and then by Badhasa $(43.57 \mathrm{mg} / 100 \mathrm{~g}$, db) variety. The lowest phosphorus content was recorded for Batte $(35.64 \mathrm{mg} / 100 \mathrm{~g}, \mathrm{db})$, followed by Mashenadima $(35.17 \mathrm{~m}$ $\mathrm{g} / 100 \mathrm{~g}, \mathrm{db}$ ) (Table 4). Tuber mineral concentrations may vary due to genotypes. There are reports that potato genotypes, grown under identical conditions, have been shown to differ in their tuber macro- and micro- element concentrations (Tekalign and Hammes, 2005).

\section{CONCLUSION}

This study showed five of the improved varieties (Badhasa, Chala, Gabbisa, Chiro, and Zemen) and two of the farmers' varieties (Batte and Mashenadima) were found to be superior in most physicochemical qualities, in a decreasing order listed above. The farmers' variety Jarso was found to be poor. Under the experimental storage tested, the potato tuber dry matter, specific gravity and amylose contents were significantly reduced, particularly beyond 40 days of storage. Variety differences significantly influenced the dry matter, specific gravity, amylose\%, crude protein, fiber, ash, potassium and phosphorus contents of the potato tubers. Potato tubers of superior physicochemical qualities were kept relatively long enough to yield still good qualities over the storage duration tested.

\section{ACKNOWLEDGMENTS}

The authors thank the Ethiopian Ministry of Education for providing the research fund and Haramaya University for granting the first author a study leave of absence for MSc Degree and for providing tubers of the potato varieties. We would also like to thank Mr. Abdullah Umar and his family members for the permission to use their potato warehouse. Centre of Research on Grain Quality, Processing and Technology Transfer (CRGQPTT) at FSPT Department and Central Laboratory of Haramaya University are acknowledged for providing technical and material supports

\section{REFERENCES}

AACC (American Association of Cereal Chemists), (2000). Approved Methods of the American Association of Cereal Chemists, $10^{\text {th }}$ ed., American Association of Cereal Chemists, St Paul: MN.

Abebe, T., Wongchaochant, S., Taychasinpitak, T. (2013). Evaluation of specific gravity of potato varieties in Ethiopia as a criterion for determining processing quality. Kasetsart Journal of Natural Science 47: 30-41.

Abong, G.O., Okoth, M.W., Karuri, E.G., Kabira, J.N., Mathooko, F.M. (2009). Levels of reducing sugars in eight Kenyan potato varietys as influenced by stage of maturity and storage conditions. Journal of Animal and Plant Sciences 2: 76-84.

Adane, H., Meuwissen, M.P.M., Tesfaye, A., Lommen, W.J.M., Lansink, A.O., Tsegaye, A. Struik, P.C. (2010). Analysis of seed potato systems in Ethiopia. Journal of American Potato Research 87: 537-552. 
Addisu S. Chemeda et al.,

AOAC (Association of Official Analytical Chemists), (1995). Official methods of analysis of the Association of Official Analytical Chemists ( $16^{\text {th }}$ ed.). Arlington, VA.

Bentini, M., Caprara, C., Martelli, R. (2006). Harvesting damage to potato tubers by analysis of impacts recorded with an instrumented sphere. Biosystem Engineering and Postharvest Technology 94: 75-85.

Bisognin, D.A., Defreitas, S.T., Brackmann, A., Andriolo, J.L., Pereira, E.I.P., Muller, D.R., Bandinelli, M.G. (2008). Physiological aging of potato tubers produced during fall and spring growing seasons and stored under different temperatures. Bragantia 67: 59-65.

Burton, W.G. (1989). The Potato. $3^{\text {rd }}$ edition. Wiley, New York, USA.

Chrastil, J. (1987). Improved colorimetric determination of amylose in starches or flours. Carbohydrate Research 159: $154-158$.

CSA (Central Statistical Agency of Ethiopia). (2012 / 2013). Agricultural sample survey for 2012/2013: Report on area and production of major crops for private peasant holdings. Statistical Bulletin No: 532. Addis Ababa, Ethiopia.

Elfnesh, F., Tekalign, T., Solomon, W. (2011). Processing quality of improved potato (Solanum tuberosum L.) variety as influenced by growing environment and blanching. African Journal of Food Science 5: 324-332.

Freitas, S.T., Isadora, E., Pereira, P., Cecília, A., Gomez, S., Brackmann, A., Nicoloso, F., Bisognin, D. A. (2012). Processing quality of potato tubers produced during autumn and spring and stored at different temperatures. Horticulture Brazil 30: 91-98.

Gould, W. (1995). Specific gravity-its measurement and use. Chipping Potato Handbook, pp.18-21.

Hrabovská, D., Heldák, J., Volnová, B. (2013). Changes in the content of vitamin $\mathrm{C}$ in potato tubers depending on variety Journal of Microbiology Biotechnology and Food Science 2(1): 2052-2058

Josée, B., Brasil, P., Marcio, P. (1993). Effects of different storage temperatures on protein quantities of potato tubers. Vegetable 5: 167-170.

Karenlampi, S.O., White, P.J. (2009). Potato proteins, lipids, and minerals. pp. 99-125. In: Singh, J and Kaur, L. (ed.). Advances in Potato Biochemistry. Elsevier Academic Publishers. Maryland, USA.

Kaur, L., Singh, J., Singh, N., Ezekiel, R. (2007). Textural and pasting properties of potatoes (Solanum tuberosum L.) as
Sci. Technol. Arts Res. J., Jan-March 2014, 3(1): 84-89

affected by storage temperature. Journal of the Science of Food and Agriculture 87: 520-526.

Kraak, A. (1993). Industrial applications of potato starch products. Industrial Crops and Products 107-112.

Lefort, J.F., Durance, T.D., Upadhyaya, M.K. (2003). Effects of tuber storage and cultivar on the quality of vacuum microwave-dried potato chips. Journal of Food Science 68(2): 690-696.

Lewu, M.N., Adebola, P.O., Afolayan, A.J. (2010). Comparative assessment of the nutritional value of commercially available cocoyam and potato tubers in South Africa. Journal of Food Quality 33: 461-476.

Luis, G., Rubio, C., Gonza'lez-Weller, D., Gutie'rrez, A.J., Revert, C., Hardisson, A. (2011). Comparative study of the mineral composition of several varieties of potatoes (Solanum tuberosum L.) from different countries cultivated in Canary Islands (Spain) International Journal of Food Science and Technology 46: 774-780

Morrrison, W.R. (1964). A fast, simple and reliable method for the micro determination of phosphorus in biological materials. Analytical Biochemistry 7: 218-224.

Nowak. (1977). Biochemical changes in stored potato tubers with different rest periods. I. Influence of storage temperature and IPC and CIPC on protein changes. Zeit Pflanzenphysiol 81: 113-124.

Randhawa, K.S., Sandhu, K.S., Kaur, G., Singh, D. (1984). Studies of the evaluation of different genotypes of potato (Solanum tuberosum L) for yield and mineral contents. Plant Foods and Human Nutrition 34: 239-242.

Rommens, C.M., Shakya, R., Heap, M., Fessenden, K. (2010). Tastier and healthier alternatives to French Fries. Journal of Food Science 75: 109-115.

Spychalla, N.P., Desborough, S.L. (1990). Fatty acids, membrane permeability and sugars of stored potato tubers. Plant Physiology 94: 1207-1213.

Susana, G. Plaza, R., Oland, J., Sueldo, M.C., Carlos, A.B. (1985). Changes in composition of potatoes (Solanum Tuberosum L.) cv. Huinkul stored in clamps. Journal of Food Science, 50: 1254-1255.

Tekalign, T., Hammes, P.S. (2005). Growth and productivity of potato as influenced by variety and reproductive growth. II. Growth analysis, tuber yield and quality. Science Horticulture 105: 29-44.

Woolfe, J.A. (1987). The Potato in the Human Diet, CIP.Lima. Cambridge University Press, Cambridge, Britain. pp. 1954. 